\title{
Rancang Bangun Pengontrol Presentasi Berbasis Slide dengan Teknik Analisis Gerakan Jari dan Tangan
}

\author{
Maisevli Harika ${ }^{1}$, Diena Rauda Ramdania ${ }^{2}$ \\ ${ }^{1}$ Dept. of IT Convergence and Engineering, \\ Pukyong National University, Rep. of Korea \\ 45 Yongso-ro Daeyeon 3(sam)-dong, Nam-gu, Busan, South Korea. \\ ${ }^{2}$ Jurusan Teknik Informatika, Fakultas Sains dan Teknologi \\ Universitas Islam Negeri Sunan Gunung Djati Bandung \\ Jl. A.H. Nasution 105, Bandung 40614 Indonesia \\ 1'maisevli@pukyong.ac.kr, 2dienarauda@pukyong.ac.kr
}

\begin{abstract}
Abstrak- Gerakan tangan mampu membantu proses berpikir karena memberikan gambaran visual pada pembicara. Memanfaatkan gerakan untuk mengendalikan presentasi berbasis slide merupakan hal yang bermanfaat dan memudahkan pembicara. Analisis gerakan tangan dalam sinar proyektor sulit dilakukan karena artikulasi tangan, occlusion, dan pencahayaan yang berubah-ubah. Pendekatan yang diajukan dalam jurnal ini didesain untuk mengendalikan presentasi berbasis slide dan pointer dengan tangan kosong.
\end{abstract}

Kata kunci-computer vision, deteksi jari, deteksi tangan, HCI, kendali gerakan tangan,slide presentasi.

\section{PENDAHULUAN}

Pernahkan anda melihat seorang presenter yang berbicara sambil menggerakkan tangan? Atau anda adalah orang tersebut? Penelitian menunjukkan, gerakan anggota tubuh dapat membantu proses berpikir seseorang ketika berbicara. Hal ini disebabkan karena gerakan tubuh dapat membantu memberikan petunjuk visual[4].

Ketika melakukan presentasi, waktu yang paling efektif untuk tetap menarik perhatian audiens adalah sekitar 15 menit. Beberapa tips dan teknik presentasi telah banyak disebar luaskan guna menjaga perhatian audiens. Tak ketinggalan, teknologi yang canggih juga turut meramaikan kebutuhan pada saat presentasi, misalnya remote control, pointer, dan kinetik control.

Kemudahan dalam menggunakan teknologi memang menjadi kebutuhan manusia. Namun, kendala teknis terkadang tak dapat dipungkiri. Seringkali presenter justru kehilangan waktu yang berharga ketika harus melakukan setting alat sebelum presentasi. Hal ini mengundang minat peneliti untuk memanfaatkan anggota tubuh manusia pada saat presentasi, misalnya tangan dan jari.

Kemampuan untuk melakukan sesuatu hanya dengan gerakan jari merupakan impian manusia sejak dulu. Dewasa ini, impian tersebut menjadi mungkin untuk diterapkan dengan memanfaatkan teknologi computer vision.
Menggunakan gerakan jari dan tangan untuk mengendalikan pointer dan navigasi slide diharapkan memudahkan pembicara yang menggunakan slide dalam presentasinya. Tulisan ini mempersembahkan desain dan implementasi dari analisis gerakan jari dan tangan menggunakan webcam untuk mengendalikan pointer dan navigasi slide presentasi.

\section{TINJAUAN PUSTAKA}

A. HSL COLOR MODEL

HSL adalah kependekan dari Hue, Saturation dan Lightness. Ketiga istilah memiliki hubungan dengan warna. Hue, Saturation, Brightness adalah aspek dari skema warna Red, Green, Blue (RGB).

Hueadalah istilah yang digunakan untuk menunjukkan suatu warna-warna dasar seperti merah, biru, hijau, kuning, coklat dan sebagainya. Perbedaan antara warna adalah perbedaan dalam hue. Sehingga hue adalah penyebutan lain dari warna itu sendiri.

Saturation adalah intensitas dari hue. Warna-warna dasar yang terang adalah warna dengan intensitas saturation tinggi. Sedangkan warna pastel/muda adalah warna dengan intensitas saturation rendah. Warna monochrome (hitam putih) sama sekali tidak mempunyai saturation.

Lightnessadalah ketajaman dari suatu warna ataupun tingkat hitam atau putih dalam skala warna. Istilah ini juga dikelan dengan value atau tone[5]. Gambar berikut ini mengilustrasikan perbedaan Hue, Saturation dan Lightness.

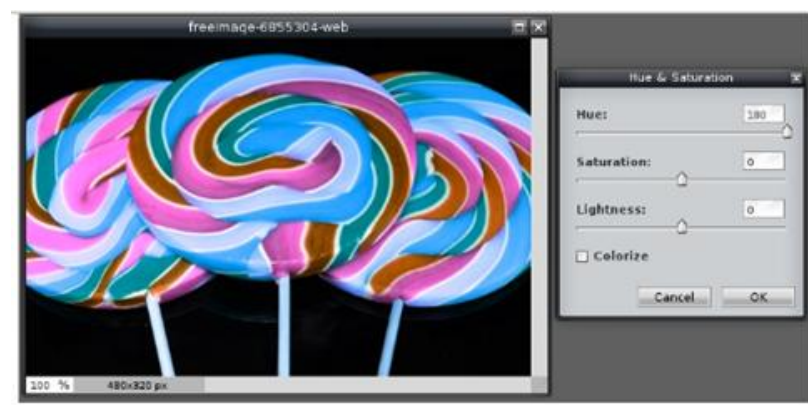

Gambar 1. Hue mengubah warna dasar menjadi biru. 


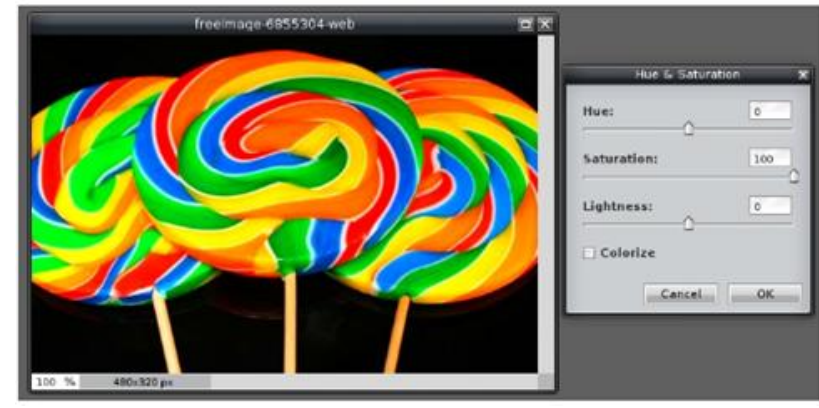

Gambar 2. Saturation.

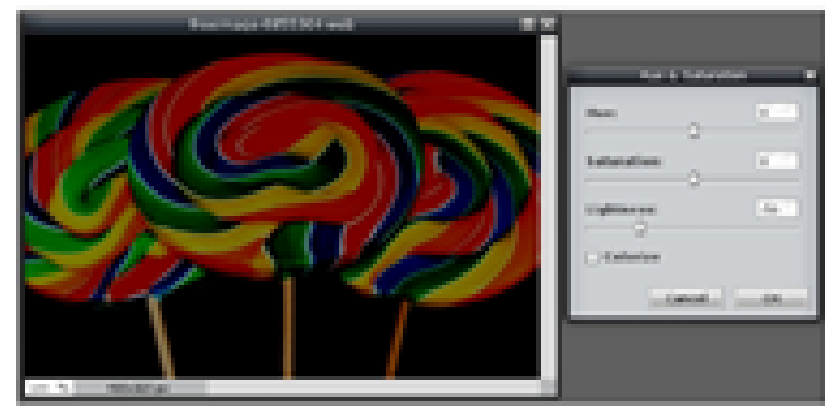

Gambar 3. Lightness.

\section{B. HSV COLOR MODEL}

Model HSV pertama kali diperkenalkan oleh A.R Smith pada tahun 1978. HSV merupakan kependekan dari Hue, Saturation, dan Value. Value dapat diartikan sebagai kecerahan dari warna. Nilainya berkisar antara 0-100\%. Semakin besar nilai maka semakin cerah dan muncul variasi-variasi baru dari warna tersebut.Apabila nilainya 0 maka warnanya akan menjadi hitam[7]. Gambar 4 mengilustrasikan HSV.

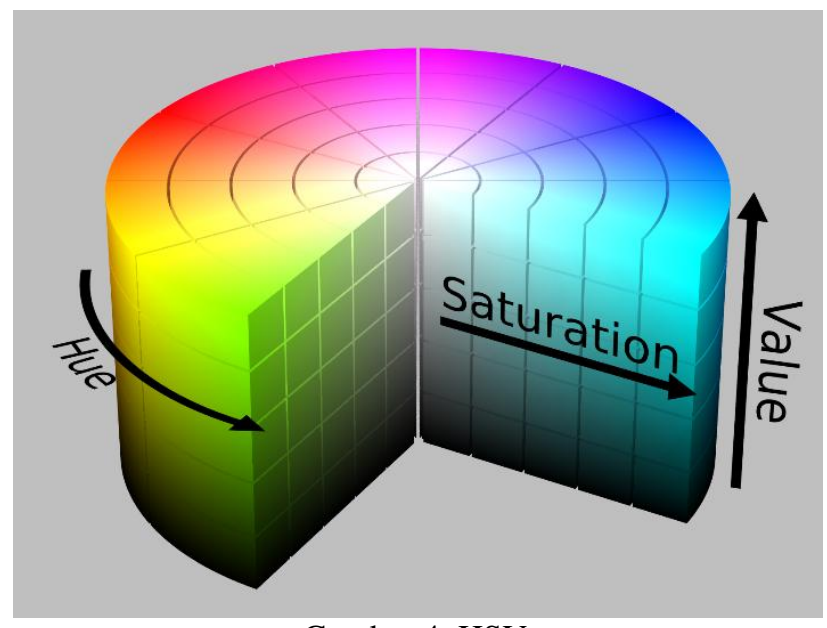

Gambar 4. HSV.

\section{KALMAN FILTER}

Kalman Filter pertama kali diperkenalkan oleh Rudolf E. Kalman pada tahun 1960. Metode ini merupakan sebuah perhitungan matematis. Secara singkat, metode ini berfungsi mengolah data yang mengandung noise menjadi data yang lebih sedikit mengandung noise. Pengolahan data tersebut mengakibatkan adanya waktu tunda (delay)[7].

\section{PENELITIAN TERKAIT}

Dewasa ini, telah banyak riset berkaitan dengan mengenali gerakan tubuh. Beberapa teknik telah ditemukan dan masing-masing memiliki pro dan kontra tersendiri. Hal ini wajar karena mengenali gerakan jari dan tangan membawa sejumlah masalah yang signifikan dan sulit untuk diselesaikan dengan algoritma yang ada sampai saat ini.

Salah satu metode yang diajukan adalah dengan menggunakan color detection untuk mengenali jari dan tangan. Teknik skin color detection digunakan oleh Rajesh et al[1] dan Jadhav et al[2] untuk mengendalikan navigasi presentasi berbasis slide. Rajesh menggunakan HSVcolor model sedangkanJadhavet al menggunakan HSLcolor model. Perbedaan yang paling mendasar adalah penggunaan Kalman filter untuk membantu menghaluskan gerakan pointer dan HSLcolor model dalam teknik adaptive skin color detection. Sedangkan kedua tim lainnya menentukan ambang batas warna kulit yang telah ditentukan untuk projek mereka. Tabel 1 berikut adalah matriks perbandingan metode yang digunakan dengan penelitian yang terkait.

Tabel 1. Matriks perbandingan sistem

\begin{tabular}{|c|c|c|c|c|}
\hline Peneliti & Alat & $\begin{array}{c}\text { Posisi } \\
\text { kamera }\end{array}$ & $\begin{array}{c}\text { Metode } \\
\text { segmentasi } \\
\text { tangan }\end{array}$ & $\begin{array}{c}\text { Metode } \\
\text { kendali slide }\end{array}$ \\
\hline $\begin{array}{l}\text { Ram } \\
\text { Rajesh et } \\
\text { al }\end{array}$ & Webcam & $\begin{array}{l}\text { Telapak } \\
\text { tangan } \\
\text { sejajar } \\
\text { dengan } \\
\text { kamera }\end{array}$ & $\begin{array}{l}\text { Static skin } \\
\text { color dalam } \\
\text { HSV color } \\
\text { model }\end{array}$ & $\begin{array}{l}\text { Menghitung } \\
\text { jumlah jari yg } \\
\text { berdiri }\end{array}$ \\
\hline $\begin{array}{l}\text { Dnyanada } \\
\text { Jadhav et } \\
\text { al }\end{array}$ & Webcam & $\begin{array}{l}\text { Telapak } \\
\text { tangan } \\
\text { sejajar } \\
\text { dengan } \\
\text { kamera }\end{array}$ & $\begin{array}{l}\text { Static skin } \\
\text { color dalam } \\
\text { HSL color } \\
\text { model }\end{array}$ & $\begin{array}{l}\text { Menggunakan } \\
\text { centroid tangan } \\
\text { untuk } \\
\text { menggerakkan } \\
\text { pointer dan } \\
\text { mengganti slide. }\end{array}$ \\
\hline $\begin{array}{l}\text { Darko } \\
\text { Martinovi } \\
\text { kj et al }\end{array}$ & $\begin{array}{l}\text { Microsoft } \\
\text { Kinect }\end{array}$ & $\begin{array}{l}\text { Seluruh } \\
\text { badan } \\
\text { sejajar } \\
\text { dengan } \\
\text { kamera }\end{array}$ & $\begin{array}{l}\text { Skeleton } \\
\text { data stream }\end{array}$ & $\begin{array}{l}\text { Deteksi gerakan } \\
\text { dengan } \\
\text { pemetaan 3D }\end{array}$ \\
\hline $\begin{array}{l}\text { Proposed } \\
\text { research }\end{array}$ & $\begin{array}{l}\text { Webcam } \\
\text { ataubuilt } \\
\text { in laptop } \\
\text { camera }\end{array}$ & $\begin{array}{l}\text { Kamera } \\
\text { menghada } \\
\text { p ke layar } \\
\text { monitor }\end{array}$ & $\begin{array}{l}\text { Adaptive } \\
\text { skin } \\
\text { colordari } \\
\text { sampel } \\
\text { awal }\end{array}$ & $\begin{array}{l}\text { Mengendalikan } \\
\text { pointer dengan } \\
\text { satu jari dan } \\
\text { centroiduntuk } \\
\text { mengganti slide }\end{array}$ \\
\hline
\end{tabular}

\section{IV.PERANCANGAN}

\section{A. DESKRIPSI SISTEM}

Sistem didesain menggunakan webcam atau built-in kamera laptop. Kamera diletakkan didepan layar. Ketika melakukan presentasi, pembicara haruslah membuat gerakan tangan di depan layar untuk mengendalikan slide.Gerakan tersebut haruslah sejajar dengan layar agar gerakan dapat dianalisis dengan baik. Ketika kamera menangkap gerakan dalam cahaya proyektor, analyzer akan menganalisis gerakan tersebut dan mengeluarkan perintah ke aplikasi sesuai dengan gerakan tersebut. Konfigurasi sistem dapat dilihat pada Gambar 5 dibawah ini. 


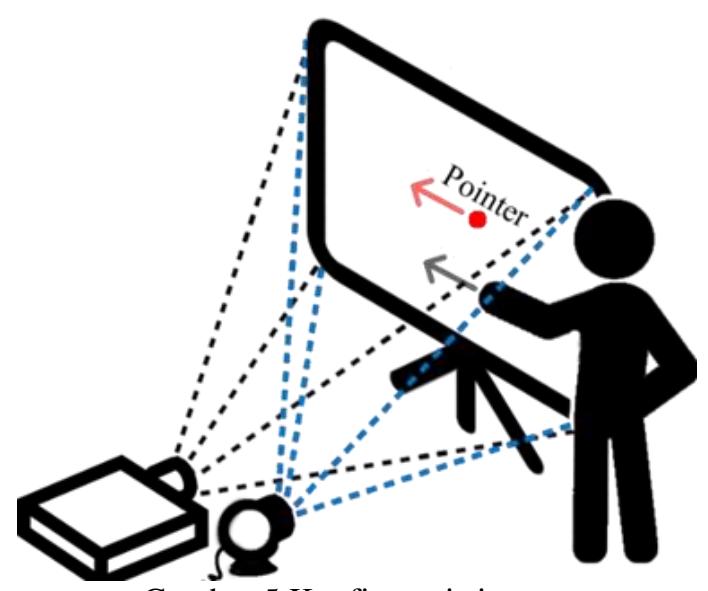

Gambar 5.Konfigurasi sistem.

Sistem terdiri dari pengambilan sampel warna untuk kulit, deteksi ujung-ujung jari, mengenali gerakan. Gambar 6 memperlihatkan pengorganisasian sistem.

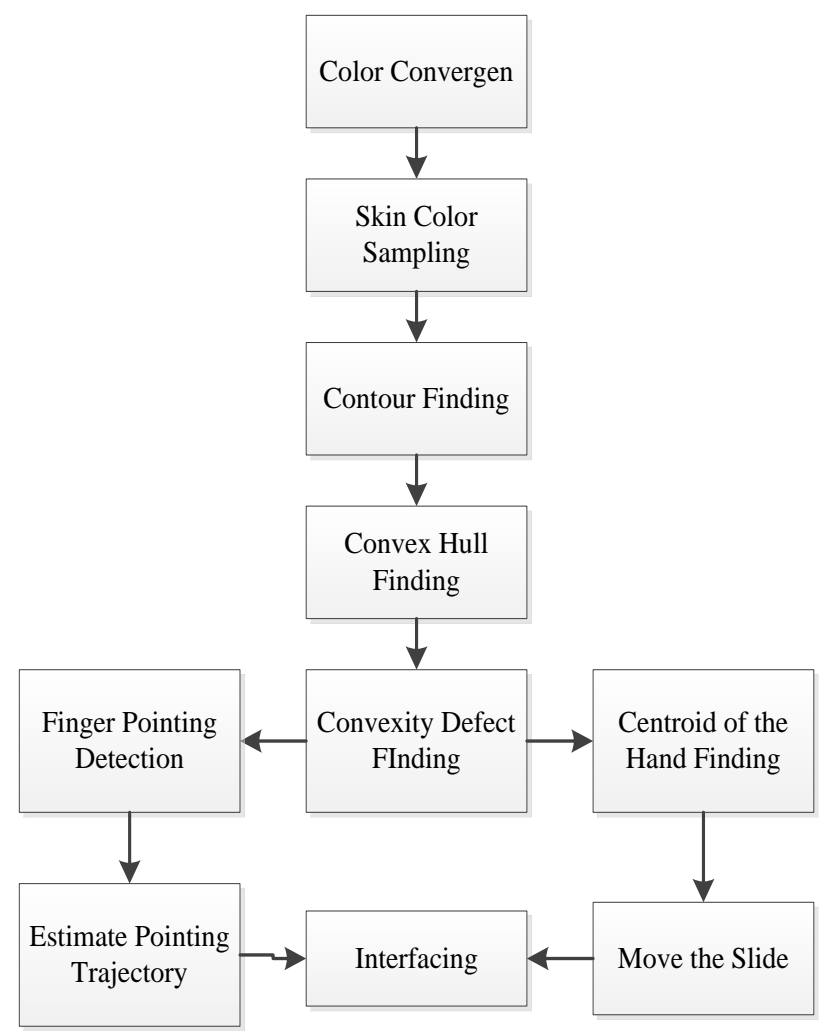

Gambar 6.Organisasi sistem

\section{B. IMAGE PROCESSING}

Image processing digunakan hampir pada keseluruhan sistem dimulai dari pengambilan sampel warna kulit, penentuan ujung-ujung jari dan tangan dengan contour detection, serta convexity defect.

Pengambilan warna kulit dimulai dengan kalibrasi warna kulit yang terkena efek dari cahaya proyektor. Sampel warna digunakan untuk menentukan ambang batas dari warna kulit untuk modul selanjutnya. Untuk menentukan ambang batas perlu ditentukan pixel dengan warna kulit dan bukan warna kulit. Proses penentuan warna kulit ini dapat dilihat pada algoritma 1 Color sampling.
Algorithm 1Color Sampling (input: color image, output: binary image)

1. Initiation: perform Equation (1), and (2)

2. $\operatorname{src}=$ input,$d s t=$ output at time $t$,

3. for $t=1$ to 30

4. convert RGB to HSL

5. for $k=0$ to 5

6. define a square ROI

7. get (src. h, src. s, src. l) values in ROI //HSL

8. for each HSL channel

9. get the median

10. $a v g+=$ the median values

11. end

12. generate $d s t$ vector from $a v g$

13. end

14. End

Pengambilan sampel warna dilakukan dalam waktu tiga puluh frame, selama pengambilan sampel sistem mengambil beberapa sampel warna, menghitung rata-rata dari masing-masing variabel $\mathrm{H}, \mathrm{S}$, dan L pada setiap ROI (Region of Interest), kemudian menentukan nilai ambang batas tertinggi dan terendah untuk setiap variabel. Pengambilan sampel warna dapat dilihat pada gambar dibawah ini.

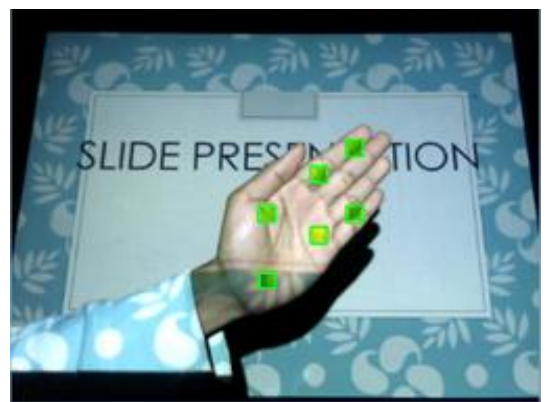

Gambar 6.Pengambilan Sampel Warna.

Proses dilanjutkan dengan me-negatifkan warnawarna lain yang dianggap bukan warna kulit (gambar biner). Batas-batas antara gambar biner tersebut di-extract menggunakan algoritma $\mathrm{K}[3]$, contour finding dan didapatlah tangan (hand detection).
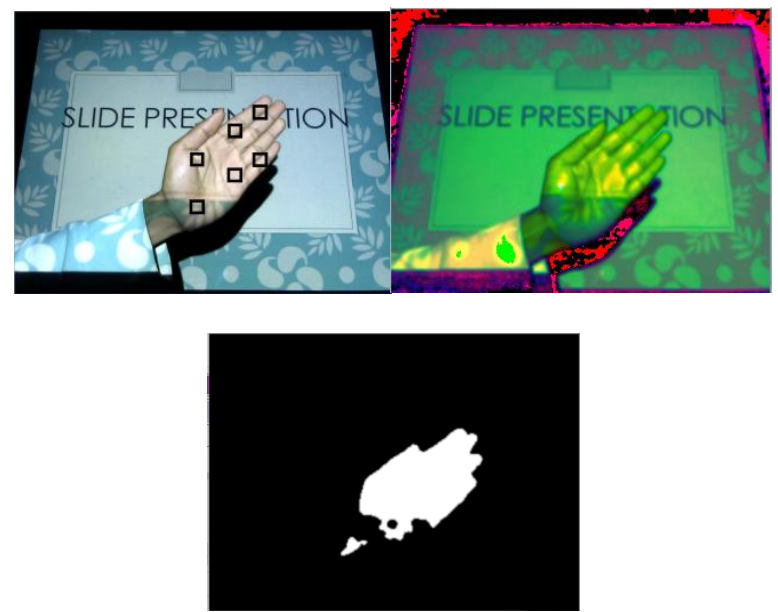
Gambar 7. Input (kiri atas), input dalam HSL (kanan atas), dan gambar biner (bawah).

Pada contour yang didapat diterapkan teknik convex hull dan convexity defect untuk mendapatkan jari. Hasil dari teknik inilah yang selanjutnya diterapkan untuk interfacing desktop.

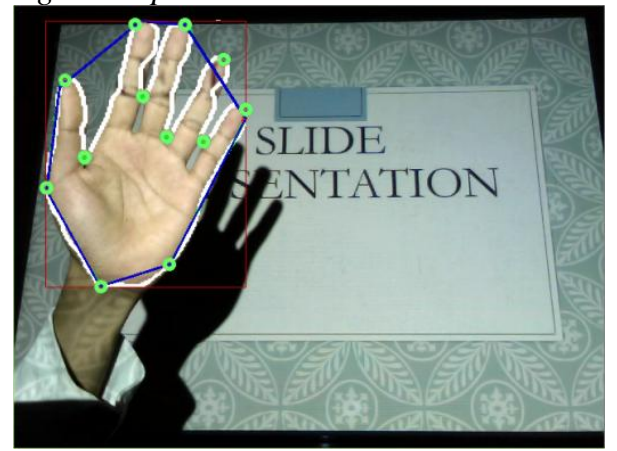

Gambar 8.Extracted Contour dan Contour Points.

Navigasi slide dan mengendalikan pointer dapat dilakukan dengan memanfaatkan titik-titik contour yang didapat pada proses implementasi convex hull dan convexity defect. Dari titik-titik tersebut dapat ditentukan ujung-ujung jari. Jumlah jari-jari ini digunakan untuk memicu navigasi dan pointing, untuk lebih jelasnya dapat diperhatikan pada algoritma berikut ini.

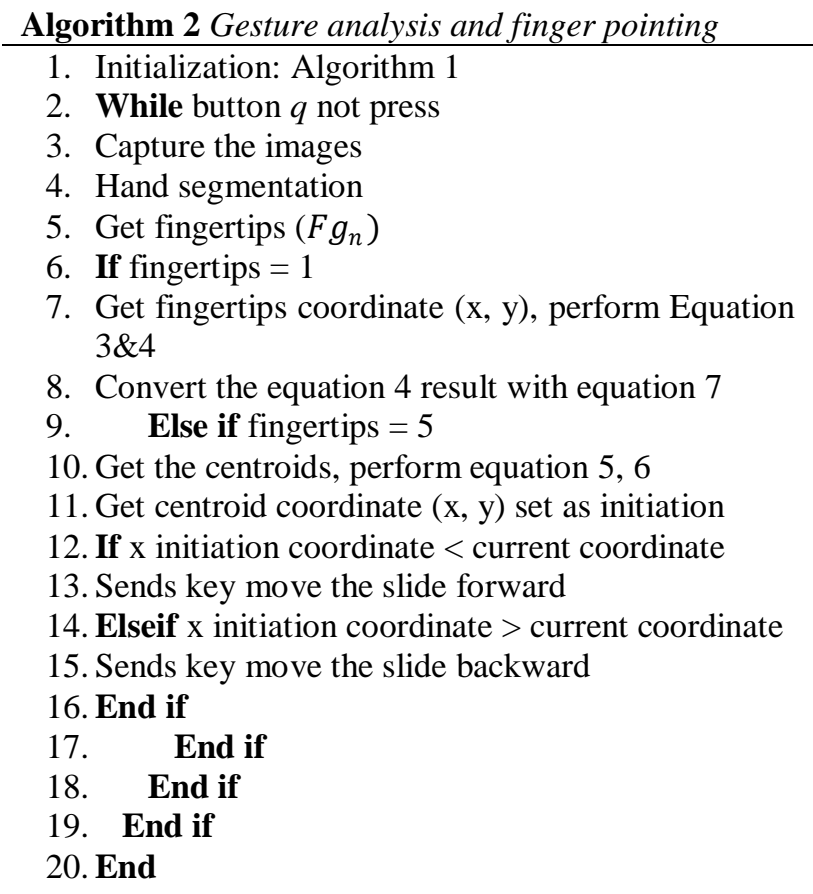

\section{NAVIGASI SLIDE}

Navigasi memanfaatkan deteksi jari dan centroid dari tangan. Navigasi slide dipicu oleh terdeteksinya lima jari dan arah perpindahan centroid menjadi penentu slide digerakkan maju atau mundur.

Centroid dideteksi saat tangan dibuka dan kelima jari terdeteksi. Titik dimana centroid kali pertama terdeteksi ditetapkan sebagai titik awal, ketika centroid bergerak titik terakhir akan dibandingkan dengan titik awal, nilai dari perbandingan ini dijadikan tolak ukur untuk menggeser slide. Centroid detentukan menggunakan moment, penentuan moment dari titik-titik contour erupakan salah satu teknik image processing.

Penulis menghitung moment menggunakan formula:

$$
\text { hand_centroid }=\left(\frac{\mu_{1,0}}{\mu_{0,0}}, \frac{\mu_{0,1}}{\mu_{0,0}}\right)
$$

Koordinat-koordinat tersebut didapat dari rata-rata koordinat $x$ dan $y$.

$$
\mu_{1,0}=\frac{\operatorname{sum}_{x}}{\mu_{0,0}} \text { and } \mu_{0,1}=\frac{\text { sum }_{y}}{\mu_{0,0}}
$$

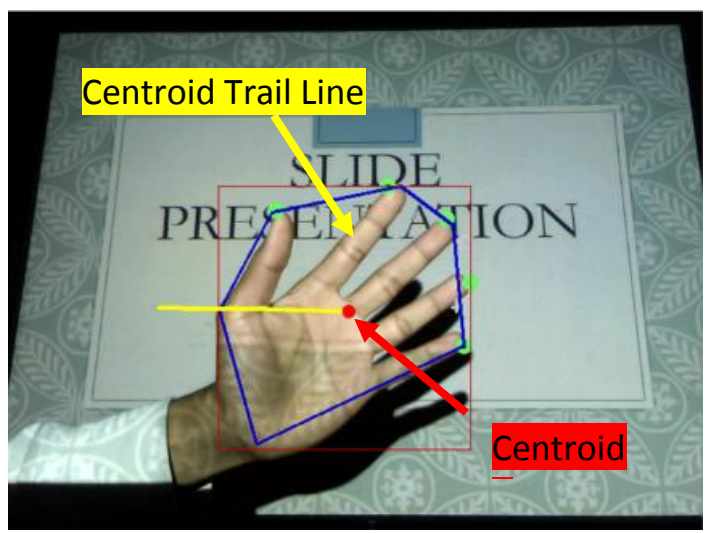

Gambar 9.Menggerakkan Navigasi Slide dengan Centroid.

Lebih ringkasnyacara kerja navigasi slide presentasi dapat dilihat pada Gambar 10 berikut.

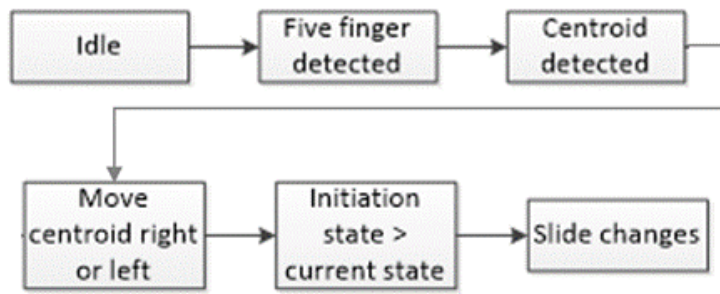

Gambar 10.Skenario untuk menggerakan slide maju atau mundur.

\section{KENDALI POINTER}

Untuk mengendalikan skenario yang dirancang adalah menggunakan satu jari, tujuan untuk mengendalikan pointer ini adalah sebagai highlight pada bahasan yang dibahas seperti penggunaan cahaya merah pada pointing device. Pada gambar berikut ditampilkan diagram alur kendali pointer.

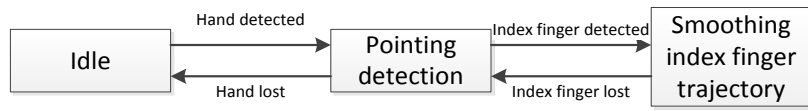

Gambar 11.Diagram alur pengendalian pointer

Gerakan tangan, karena efek pencahayaan dibutuhkan Kalman filter untuk memuluskan pergerakan pointer, karena pergerakan yang tertangkap akan shaky karena pengaruh noise dan pencahayaan. Kami menentukan gerakan tangan sebagai input dan rumus 
smoothing trajectory menggunakan Kalman filter adalah sebagai berikut.

$$
y_{t}=B x_{t}+v_{t}
$$

dengan $B$ merupakan matrix opservasi dari vektor $x_{t}$ dan $v_{t}$ digunakan untuk mengukur noise pada waktu $t$. Vektor opservasi $y_{t}$ merupakan posisi jari yang diinginkan, $x_{t+1}$ digunakan untuk smoothing trajectory dari posisi jari, rumus sebagai berikut.

$$
x_{t+1}=A x_{t}+w_{t}
$$

$A_{x t}$ merupakan pemodelan yang digunakan untuk prediksi ditambah Gaussian white noise processw $w_{t}$ untuk menentukannilai $x$ pada waktu $t+1$.

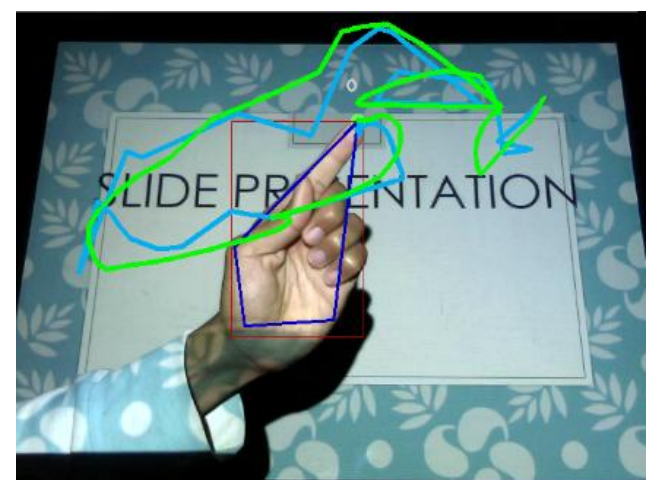

Gambar 12.Finger pointing trajectory and estimation trajectory.

\section{E. INTERFACING}

Proses terakhir adalah membangun antarmuka atau interfacing. Kita harus membangun antarmuka antara vision system dan perangkat lunak Powerpoint. Perintahperintah dari vision system dikirim ke perangkat lunak untuk presentasi ini menggunakan sends key, salah satu fungsi dari Microsoft Windows untuk mengirim input ke sistem operasinya.

Koordinat pointing gesture akan sangat berbeda dan dibutuhkan penyesuaian pada desktop, untuk memetakan lokasi jari ke ukuran monitor presentasi digunakan fungsi berikut.

$$
f: p \rightarrow d=\left(\frac{P x}{d x} W, \frac{P y}{d y} H\right)
$$

Dengan, $p$ merupakan posisi pointer pada desktop presentasi, $d$ posisi pointing pada sistem, $P x$ dan $P y$ merupakan koordinat pada sistem, $d x$ dan $d y$ merupakan dimensi tampilan, dan $W$ dan $H$ merupakan dimensi pergerakan tangan pada sistem.

\section{PERCOBAAN DAN ANALISIS}

Hasil evaluasi dari sistem digunakan untuk mengukur performa dari sistem. Beberapa percobaan telah dilakukan untuk mengukur kemampuan dari sistem. Analisis sistem ini dilakukan untuk menentukan apa saja yang dbutuhkan untuk meningkatkan kemampuan dari sistem untuk penelitian lanjutan.

Analisis pertama adalah untuk mengukur kemampuan sistem dalam menangkap warna kulit, analisis kedua adalah mengukur seberapa akurat sistem menangkap satu jari. Selanjutnya penelitian untuk mengukur keakuratan sistem untuk menggeser slide ke kiri atau ke kanan. Percobaan-percobaan dilakukan oleh 5 orang sampel yang diambil secara acak.

\section{A. DETEKSI WARNA KULIT}

Penelitian pertama ini untuk mengukur kemampuan

\begin{tabular}{|c|c|c|c|c|c|c|c|}
\hline \multirow[b]{2}{*}{ User } & \multicolumn{2}{|c|}{ Percobaan 1} & \multicolumn{2}{|c|}{ Percobaan 2} & \multicolumn{2}{|c|}{ Percobaan 3} & \multirow{2}{*}{$\begin{array}{c}\text { Succe } \\
\text { ss } \\
\text { Rate }\end{array}$} \\
\hline & $\begin{array}{c}\text { Succ } \\
\text { ess }\end{array}$ & Fail & $\begin{array}{c}\text { Succe } \\
\text { ss }\end{array}$ & Fail & $\begin{array}{c}\text { Succ } \\
\text { ess }\end{array}$ & Fail & \\
\hline 1 & 41 & 9 & 27 & 23 & 39 & 11 & \multirow{5}{*}{$\begin{array}{c}72.4 \\
\%\end{array}$} \\
\hline 2 & 39 & 11 & 31 & 19 & 37 & 13 & \\
\hline 3 & 45 & 5 & 37 & 13 & 44 & 6 & \\
\hline 4 & 41 & 9 & 32 & 18 & 40 & 10 & \\
\hline 5 & 40 & 10 & 29 & 21 & 36 & 14 & \\
\hline
\end{tabular}
deteksi warna kulit.

Tabel 2. Hasil Deteksi warna kulit.

\section{B. DETEKSI JARI POINTING}

Percobaan ini dilakukan untuk mengukur tingkat kesuksesan deteksi pointing gesture dengan menghitung jumlah frame dimana pointing gesture terekam dalam satu menit.

Tabel 3. Hasil pengujian deteksi pointing gesture.

\begin{tabular}{|c|c|c|c|c|}
\hline User & Frames & $\begin{array}{c}\text { Total } \\
\text { Fingertips }\end{array}$ & Failed Fingertip & \multirow{2}{*}{ Accuracy } \\
\hline $\mathbf{1}$ & 1739 & 1306 & 433 & \\
$\mathbf{2}$ & 1693 & 1254 & 439 & \multirow{2}{*}{$\mathbf{7 4 . 0 \%}$} \\
\hline $\mathbf{3}$ & 1823 & 1353 & 470 & \\
\hline $\mathbf{4}$ & 1984 & 1385 & 599 & \\
\hline $\mathbf{5}$ & 2074 & 1595 & 479 & \\
\hline
\end{tabular}

\section{NAVIGASI SLIDE}

Tingkat kesuksesan mengendalikan slide menggunakan gerakan tangan diukur dengan keberhasilan menggeser slide maju dan mundur sebanyak 50 kali.

Tabel 4. Hasil pengujian navigasi slide.

\begin{tabular}{|c|c|c|c|c|c|c|}
\hline \multirow{2}{*}{ Trial } & \multicolumn{2}{|c|}{ Move Forward } & \multicolumn{2}{|c|}{$\begin{array}{c}\text { Move } \\
\text { Backward }\end{array}$} & \multicolumn{2}{|c|}{ Accuracy } \\
\cline { 2 - 5 } & $\begin{array}{c}\text { Succes } \\
\text { s }\end{array}$ & Fail & $\begin{array}{c}\text { Succ } \\
\text { ess }\end{array}$ & Fail & Forward & $\begin{array}{c}\text { Backwar } \\
\text { d }\end{array}$ \\
\hline $\mathbf{1}$ & 39 & 11 & 42 & 8 & & \\
\hline $\mathbf{2}$ & 40 & 10 & 38 & 12 & \multirow{2}{*}{$\mathbf{7 6 . 4 \%}$} & \multirow{7}{\mathbf{77.2\%}}{} \\
\hline $\mathbf{3}$ & 37 & 13 & 38 & 12 & & \\
\hline $\mathbf{4}$ & 38 & 12 & 37 & 13 & & \\
\hline $\mathbf{5}$ & 37 & 13 & 38 & 12 & & \\
\hline
\end{tabular}

\section{KENDALI POINTER}

Penelitian dilakukan dalam waktu 100 detik dengan status keberhasilan dinilai dari tidak hilangnya pointer saat pointing.

Tabel 5. Hasil pengujian pointer pointing.

\begin{tabular}{|c|c|c|c|}
\hline Trial & Success & Fail & \multirow{2}{*}{ Success rate } \\
\hline $\mathbf{1}$ & 89 & 11 & \multirow{3}{*}{$\mathbf{8}$} \\
\hline $\mathbf{2}$ & 78 & 23 & \\
\hline $\mathbf{3}$ & 84 & 16 & \\
\hline $\mathbf{4}$ & 61 & 39 & \\
\hline $\mathbf{5}$ & 88 & 12 & \\
\hline
\end{tabular}

\section{KESIMPULAN DAN SARAN}

Berdasarkan penelitian yang dilakukan, terbukti metode yang digunakan mampu untuk menggantikan peralatan antarmuka yang biasa digunakan dalam 
presentasi (mouse dan keyboard), tanpa memandang warna kulit dan ras penggunanya.

Penulis menyarankan untuk meningkatkan kemampuan aplikasi yang menggunakan teknologi computer visiondengan memanfaatkan background substraction bersamaan dengan metode yang digunakan saat ini mungkin mengatasi masalah dengan presentasi yang kaya akan warna. Background-sucstraction mengambil foreground dari background-area. Dengan memanfaatkan hal ini akan didapat foreground dari gerakan tangan. Foreground ini mencakup siluet tangan yang bergerak dan bayangan tangan, karena bayangan tangan juga menjadi dominan di dalam sinar proyektor. Karena hal inilah metode background-substraction masih membutuhkan metode lain misalnya color-detection. Selanjutnya penambahan skenario untuk fitur aplikasi seperti mengambar shape, free draw atau menulis dengan gerakan tangan merupakan hal yang menarik untuk dilakukan.

\section{REFERENSI}

[1] Rajesh, Ram., Nagajunan. Arunachalam. Aarthi. (2012). Distance Transform Based Hand Gestures Recognition for Powerpoint Presentation Navigation. Proceedings of the Advanced Computing: An International Journal, vol.3, pp $41-48$.

[2] Jadhav, Dnyanda. dan L.M.R.J. Lobo. (2015). Proceedings International Journal of Science and Research (IJSR), vol. 4, pp $883-837$.

[3] Suzuki, S., dan Abe, K., (1985). Topological Structural Analysis of Digitized Binary Images by Following, Computer Vision, Graphics, and Image Processing, vol. 30., pp $32-46$.

[4] Dcience Daily, (2011). Gerakan anggota tubuh saat berbicara bantu proses berpikir. http://nationalgeographic.co.id/berita/2011/01/gerakananggota-tubuh-saat-berbicara-bantu-proses-berpikir, diakses tanggal: 14 Desember 2016.

[5] Al-Arkam, (2015). Mengenal Hue, Saturation, dan Lightness.

http://mbah4us.blogspot.co.id/2015/12/mengenal-huesaturation-lightness.html? $\mathrm{m}=1, \quad$ diakses tanggal: 12 Desember 2016.

[6] Abd Fauzan (2015). Ruang Warna HSV serta Konversinya. http://www.charisfauzan.net/2015/01/ruangwarna-hue-saturation-value-hsv.html, diakses tanggal: 12 Desember 2016.

[7] Greg Welch, Gary Bishop, (2001), An Introduction to The Kalman Filter, Course 8. http://www.cs.unc.edu/ tracker/media/pdf/SIGGRAPH20 01_CoursePack_08.pdf. Diakses tanggal: 10 Desember 2015 . 